\title{
The crowding-out effect of elderly support expenditure on household consumption from the perspective of population aging: evidence from China
}

\author{
Congjia Huo(D, Guoan Xiao and Lingming Chen * (D)
}

\author{
*Correspondence: lingming1016@ \\ mail.hnust.edu.cn \\ School of Business, Hunan \\ University of Science and \\ Technology, No. 1, Taoyuan Road, \\ Yuhu District, 411201 Xiangtan, \\ China
}

\begin{abstract}
The pace of aging in China is accelerating, from the introduction of family planning to the liberalization of the two-child policy, with a growing proportion of families in the 4-2-1 structure. With filial piety in mind, most adult children will live with their elderly parents and share income and expenditure. Concurrently, due to the inadequacy of the social security system, a heavy supplementary burden of supporting the elderly has been placed on adult children. Based on data from the 2011, 2013, 2015, and 2017 Chinese Social Survey (CSS) of the Chinese Academy of Social Sciences (CASS), this study analyzes the objective factors affecting household elderly support expenditure using the ordinary least squares (OLS) estimation method. It also examines the crowding-out effect of elderly support expenditure on the consumption of different types of households through a panel generalized method of moments (GMM) approach. Finally, the crowding-out effect of elderly support expenditure is discussed in a sub-sample according to the number of households needing to support the elderly aged 60 and above. The empirical results illustrate that there is a crowding-out effect of elderly support expenditure on household consumption, and the magnitude of the crowding-out effect varies for diverse consumption. Our study reveals that the crowding-out effect of elderly support expenditure on core consumption is the largest in a sample with different numbers of elderly persons in families. The empirical results for the sub-sample show that the larger the elderly population, the stronger the crowding-out effect of elderly support expenditure on core consumption and the less pronounced the effect on marginal consumption.
\end{abstract}

Keywords: Aging, Household, Consumption, Intergeneration, Crowding-out effect

\section{Introduction}

According to World Bank data, the world's aging population grows by 3\% every year with the age of over 60 as the dividing line. By 2016, the global aging rate had been 8.48\%. In 2017, the elderly population reached 962 million, accounting for $13 \%$ of the total population (United Nations 2017) - these data far exceed international standards.

(c) The Author(s). 2021 Open Access This article is licensed under a Creative Commons Attribution 4.0 International License, which permits use, sharing, adaptation, distribution and reproduction in any medium or format, as long as you give appropriate credit to the original author(s) and the source, provide a link to the Creative Commons licence, and indicate if changes were made. The images or other third party material in this article are included in the article's Creative Commons licence, unless indicated otherwise in a credit line to the material. If material is not included in the article's Creative Commons licence and your intended use is not permitted by statutory regulation or exceeds the permitted use, you will need to obtain permission directly from the copyright holder. To view a copy of this licence, visit http://creativecommons.org/licenses/by/4.0/. 
In the 1950s, the phenomenon of population aging first appeared in developed countries in Europe and the United States. By the end of the 1970s, most developed countries had aging populations. At the beginning of the 21st century, China began to experience population aging.

This demographic transition has been one of the major changes in human society in the past 300 years and has had a major impact on the formation of modern society, urbanization and urban growth, social and economic development, and so on (Dyson 2013). A country or region is considered an aging society when the population of people over 60 years old accounts for $10 \%$ of the total population, or the population of people over 65 years of age accounts for $7 \%$ of the total population. With the increase in life expectancy and the decline in fertility, China is currently experiencing an unprecedented demographic transition. The proportion of children aged 0-14 was $35.79 \%$ in 1949. In the past 36 years, this proportion has dropped to $16.41 \%$ (State Council 1985). The proportion of people aged 65 and above rose from 4.15\% in 1949 to $12.63 \%$ in 2019 (Wang 2019). In 2017, China's aging population reached 240 million, ${ }^{1}$ and China's demographic structure has gradually changed from a "pyramid" to a "spindle shape." China's domestic quality of life is low as compared to that of developed countries, with a GDP per capita of USD 9481.881 in 2017 (United Nations 2018), 70th in the world according to GDP per capita among countries, which is below the global average of USD 10,714.47 (World Bank 2018). China has a GDP per capita has not yet reached the global average of USD 10,714.47. Compared to other developing countries, China's 's aging rate is much higher than 13\% of Brazil, $10 \%$ of Mexico, and $8 \%$ of South Africa (United Nations 2018). Wang et al. 2019 show the main characteristics of China's aging: First, the total population of the elderly is large; second, the aging rate increases rapidly and has increased from $4.9 \%$ (1982) to 10\% (1999) in just 18 years; third, the growth rate of GDP per capita cannot keep up with the speed of population aging.

Although the main reason for China's population structure change was the introduction of the national family planning policy, the study found that a certain class of Chinese people (such as those with higher income and education) started experiencing a decline in fertility at the end of the 1950s. The phenomenon of aging, accompanied by low fertility, has caused the disappearance of demographic dividends. The number of laborers has decreased from 2012, and more seriously, the aging population has increased the burden on social pension and family pension.

Figure 1 shows the trend of China's aging population and GDP per capita. The GDP per capita $(p g d p)$ is based on the 1978 population, and it increased to RMB2380.8 in 2017. Aging rate (oldr\%) refers to the proportion of the population aged 60 years and above in the total population. The burden ratio of aging population (oldb\%) is defined as the proportion of people aged 65 and above in the population aged 15-65 years. The data of oldr and oldb in Fig. 1 are only continuous data after 1990, and the data of $p g d p$ are from 1978 to 2016. In 1982, the burden ratio of aging population and the aging rate were $7.98 \%$ and $4.9 \%$, respectively. By 2017 , these ratios were $11.4 \%$ and $15.86 \%$, respectively. The gaps are getting bigger and bigger, and the burden of pensions is getting heavier and heavier. The social pension system was started late and was not perfect. As a result, the family had to bear some of the burdens of old-age care.

${ }^{1}$ Data source: Calculated according to the census data of 1953 and 2010 and 2018 China Statistical Yearbook. 


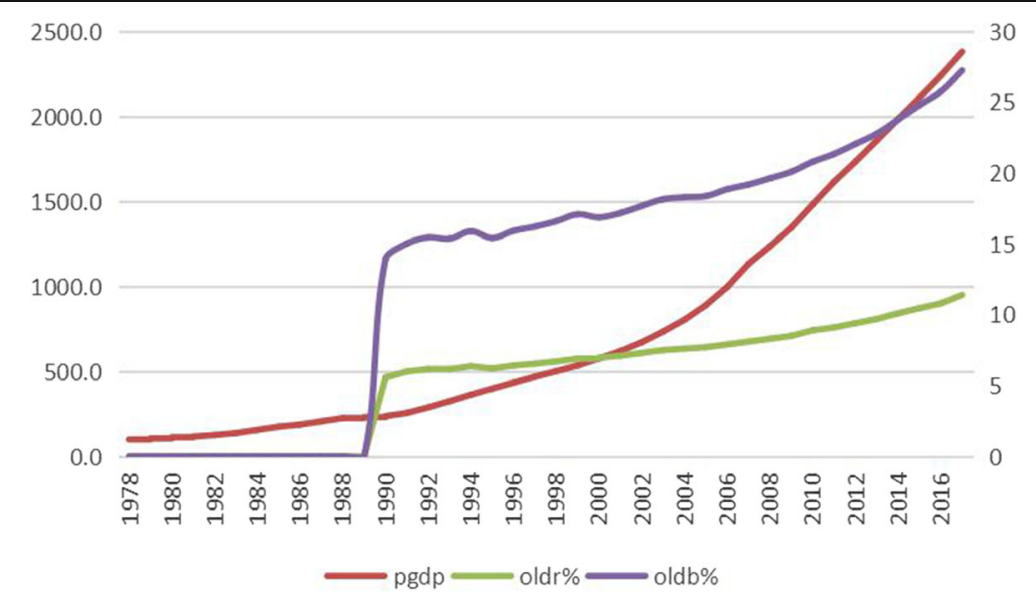

Fig. 1 Trend of China's population aging and GDP per capita. Source: The China Statistical Yearbook 2018, including data on GDP per capita (pgdp) and aging rate (oldr\%) and burden ratio of aging population (oldb\%) in 1982, 1987, and 1990-2015. The left axis shows GDP per capita; the first right axis shows the aging rate; the second right axis shows the aging burden ratio

In Maslow's (1954) hierarchy of needs theory, people's needs are divided into five levels, from low to high: physiological need, safety need, love and belongingness, selfesteem, and self-actualization. Only those who first realize the low-level needs are qualified to pursue high-level needs. According to the consumption connotation defined by the "Core Consumption Determinism" proposed by Long and Wang (2015), this article simply classifies all consumption into three categories, namely, daily consumption, core consumption, and marginal consumption. Daily consumption refers to the use of goods or services that people need to maintain daily life. It mainly includes food, clothing, water, electricity, gas, communications, transportation, human relations, and other expenses. Core consumption refers to the consumption of goods and services considered essential in life. Such priority expenditures mainly include rent, house purchase, housing renovation, medical care, and education expenditure (elderly support expenditure is calculated separately). Marginal consumption refers to consumption that is optional in life; this mainly includes the purchase expenditures for household appliances, furniture, household vehicles, decoration, culture, entertainment, tourism, and so on. Daily consumption in the household consumption category corresponds to physiological needs, which is to meet the basic needs of human life; core consumption includes medical care and education, corresponding to safety needs; marginal consumption corresponds to love and belongingness and self-esteem. Marginal consumption will be considered only after daily consumption and core consumption are satisfied. The greater the number of elders who need support, the higher the support expenditure. When elderly support expenditure reaches a critical point, it will change the family's original consumption pattern to selectively reduce its expenditure to meet the needs of supporting elders. Every family has different consumption preferences, but as a rational choice, one must first satisfy daily and core consumption before satisfying marginal consumption. Once elderly support expenditure takes a significant share of the family income, different families will naturally make different adjustments. When the family income is high enough to meet marginal consumption, marginal consumption is the first to be crowded out, with priority on daily 
and core consumption; when the family income is low, the family has no marginal consumption, and an increase in elderly support expenditure can only crowd out daily and core consumption. Presently, China's 4-2-1 family structure has made supporting the elderly a heavy burden, and under the premise of a certain family income, people can only adjust the proportion of resource allocation to meet various consumption needs. With the increase in family living costs, the ratio of household investment spending has inevitably gone out of balance. Housing, medical treatment, education, and old-age care are four mountains that weigh on young and middle-aged people. The high cost of living may reduce other household consumption.

Related studies have not yet reached a consensus on the impact of aging on household consumption. Some scholars believe that aging greatly affects Chinese household consumption, while others have shown that aging has no significant impact on overall household consumption. The purpose of this study is to use detailed data on household consumption in the Chinese Social Survey (CSS) of the Chinese Academy of Social Sciences (CASS) to examine the crowding-out effect of elderly support expenditure on Chinese household consumption in the context of aging. We also pay attention to the macro effect of aging on consumption-that is the shrinking of the total consumption demand after the shrinking of household consumption. The key contributions of this study are reflected in the following. First, the variable of "the number of elderly people aged over 60 who need support in the household" has been introduced in this study, and since the CSS data provide information on household elders in detail, the elders include own parents, grandparents, spouse's parents, and spouse's grandparents. All these categories of elders have been used to calculate the number of elderly people. Second, in terms of research methodology, we recognize that residential consumption expenditure is essentially based on households, and unlike other studies, this study decomposes consumption into daily consumption, core consumption, and marginal consumption, and then examines the degree of crowding-out of elderly support expenditure on different types of consumption. Third, this study provides new micro-evidence of the crowding-out effect of the aging population on household consumption. Our study has found that elderly support expenditure will indeed squeeze the family consumption of adult children, and the crowding-out effect is different in samples with different numbers of elderly people. In the same sample, the crowding-out effect varies for different types of consumption. Understanding the association between household consumption and the aging of the population will help improve the social pension system, stimulate household consumption, and improve the propensity to consume to increase social welfare.

The rest of the paper is structured as follows. Literature review section reviews the literature. Institutional background section provides the institutional background of China's pension development and discusses the inevitability of family pension as a supplement for the elderly. Data source and descriptive statistics section introduces the sources of data and factors affecting the expenditure of dependent parents. Model construction and empirical results section elaborates on the empirical model and presents the results and discussion. Finally, Conclusion section presents the research summary and implications.

\section{Literature review}

Aging not only leads to an imbalance in the demographic structure but also increases the proportion of the economically inactive population relative to the economically 
active population. The balance of intergenerational mobility has been broken, and many countries have fallen into the predicament of supporting the elderly. More and more elderly people are placing an incalculable burden on adults. As the quality of life continues to improve with age, so does the pension burden of future generations (Höpflinger and Hugentobler 2003). At the same time, the proportion of the elderly population who cannot get enough pensions increases; the living standards of the elderly will inevitably decline, and the care they receive will also decrease (Goldin 2016). A country with a mature welfare system should provide sufficient pensions for the elderly to ensure their quality of life, but the governments of most countries in the world cannot fully support the elderly. Therefore, beside the pension system, families also assume part of the pension responsibility. In China, the elderly in urban areas are mainly supported by social pension, while the elderly in rural areas are mainly supported by family members. However, whether in urban or rural areas, family support is still the main avenue to provide for the elderly (Lin et al. 2014). Social pension also bears part of the pressure of elderly care, but it has a limited substitution effect for elderly care (Zhang and Chen 2014).

From a macro perspective, the aging of the population will affect a country's income distribution and consumption preferences. This is because of the role of the elderly in the demographic structure and its peculiarities. The aging of the population will inevitably have a great impact on the politics, economy, and culture of a country or region. It will affect the distribution of income in terms of savings, capital, taxation, the labor market, and so on (Zhu 2016). Besides, the accelerated process of population aging will decrease national savings and, to a certain extent, household consumption, which is not conducive to economic growth (You and Cai 2017). The restructuring of household consumption due to population aging is mainly achieved by the increase in the proportion of consumption expenditure on health care. However, the impact on the proportion of household expenditure on transportation and communication consumption, as well as the expenditure on culture, education, and entertainment, is negative. The upgrading effect of the consumption structure of an aging population is stronger in rural areas than in urban areas (Wang and Liu 2017). Some scholars believe that the aging population has increased the consumption level of urban households. Thus, the government should vigorously develop the aging industry and drive elderly consumption through the "silver hair industry" (Wang and Zhou 2019).

From a micro perspective, we should first clarify the inevitability of adult children supporting their parents. In sociology, there are three motives regarding the relationship between adult children and their parents: mutual benefit, affection, and responsibility. From the exchange theory perspective, intergenerational support between children and parents is the most classic example of exchange in human life (Hareven 1978). Parents invest a high amount of human capital in return for financial support and living care in their old age from their children (Becker 1974; Diamond 1965). Raising children has become another form of and substitute for parents' pension savings (Becker 2009). Parents spend a lot of time, energy, and money on raising children (Kotlikoff 1988). Therefore, children will spend time and energy to take care of their parents when they are old, and a certain percentage of adult children will take the initiative to support their parents (McGarry and Schoeni 1995). Research on aging cannot ignore the impact of increased pressure on children to support the elderly. The 
presence of the elderly at an advanced age will affect the family's income and expenditure and place huge economic pressure on children with lower income (Lai 2012).

In China, most adult children need to bear the expenditure of their elderly parents. Most adult children are willing to take care of their elderly parents, no matter how much support their parents have given to them before (Schwarz et al. 2010). In contrast to the Western intergenerational reciprocal model, "filial piety" is a very important part of Chinese traditional Confucian culture (Yin 2009). The diverse cultural traditions have made Western scholars be interested in the behavior of adult children supporting their parents in East Asia (Greenhalgh 1985; Ofstedal et al. 1999; Ogawa and Retherford 1997). The convention in East Asian countries is that only sons are required to support their parents, and daughters have no responsibility to support. However, at present, the elderly support role of daughters in urban areas in China is higher than that of sons (Xie and Zhu 2009; Xu 2015). Different generations of the population have differences in thinking and behavior due to their different backgrounds, that is, their birth years and the environments in which they grew up (Egri and Ralston 2004; Liang 2014). Even if it violates the custom, the married daughter must be included in the pension responsibility, which in itself represents the dilemma of Chinese youth in an aging society. Under the current situation of changes in family structure and insufficient pension resources for the elderly, adult children support will affect parents' pension choices. This situation is more obvious in one-child families, where parents will rely more on their children for support (Abraham 1954; Feng and Ma 2019). China made family planning a basic national policy in the 1982 Constitution and implemented the one-child policy for decades. The two-child policy was not liberalized until 2016. Chinese households have an extremely peculiar 4-2-1 structure, which is a family consisting of only two adult children who need to support four elderly people and two children. The increasing pension burden will inevitably squeeze the consumption of adult children. To better support the elderly, young people will reduce their expenditure. Aging will not only reduce household consumption but also have different effects on different consumption types (Shi et al. 2019).

Previous literature mainly analyzed the impact of aging on household consumption from the perspective of the aging population itself or generally discussed the support burden of adult children with aging parents. Few studies have analyzed the crowdingout effects of aging households on other household consumption. The pressure of oldage pension is increasingly heavy. Once parents become old, their pension is not enough to ensure the quality of life. Do children need to reduce their consumption to make up for elderly support expenditure? Does maintenance expenditure cause a crowding-out effect on household consumption? If so, how big is the crowding-out effect? This study examines the crowding-out effect of elderly support expenditure in the context of aging.

\section{Institutional background}

There are three levels in China's current pension system. The first level is the three major state-led basic insurance systems. The three major systems are the basic endowment insurance system for urban enterprise employees, the basic endowment insurance system for government agencies and institutions, and the basic endowment insurance for urban and rural residents. The first two systems have the same model, but they run 
separately. At the second level, the enterprise-led occupational pension system includes enterprise annuities and occupational annuities. At the third level, which is an individual-led level, individuals voluntarily participate in tax-deferred pensions. These three levels correspond to the first, second, and third pillars of the internationally accepted three-pillar pension system.

The first level is primarily dominated by the state. At the end of 2008, only 219 million Chinese people had basic pension insurance. Before 2009, China's pension insurance system covered only urban workers. In 2009, the new rural pension insurance system was piloted and then fully promoted. In 2011, China commenced the basic endowment insurance system for urban residents, and China's pension insurance coverage expanded rapidly. In 2015, the State Council of the People's Republic of China promulgated the Decision on the Reform of the State Employee Pension System. It is proposed that staff of government agencies and institutions implement a basic pension insurance system that combines social pooling with individual accounts. By the end of 2017, the number of people participating in China's pension insurance exceeded 915 million, ${ }^{2}$ and pension insurance was a full-coverage system. With the gradual expansion of the coverage of the pension system, the number of pensions increased progressively. Especially in the past 10 years, pension benefits have increased every year. At present, the average pension for urban enterprises is RMB2491 per month. By 2017, the basic pension level for urban and rural residents reached RMB124 per month. ${ }^{3}$

The second level is the enterprise-led occupational pension system. In 2004, the Chinese government issued the Trial Measures for Enterprise Annuity and the Trial Measures for the Management of Enterprise Annuity Funds. These two documents determined the specific operational specifications of the enterprise annuity. By 2017, the number of enterprises participating in the enterprise annuity reached 80,400, and the number of employees participating in the enterprise annuity reached 23.31 million. Furthermore, the accumulated balance of the enterprise annuity funds reached RMB1288.8 billion. ${ }^{4}$ Besides, the Measures for Occupational Annuity of Government Offices and Public Institutions announced by the State Council stipulate that the occupational annuity system for the staff of government agencies and institutions was to be implemented from October 1, 2014. There are nearly 40 million employees in China's government agencies and institutions in 2017. According to the regulations, it is estimated that the number of people participating in occupational pension insurance is about 40 million in $2017 .^{5}$ The third level is the individual's initiative to pay taxdeferred pensions. In April 2018, the Chinese government issued the Notice on Launching the Pilot Program for Individual Tax-Deferred Commercial Pension Insurance and decided to pilot individual tax-deferred commercial pension insurance in some areas. The pilot project adopted Exempting and Taxing (EET)'s tax incentives. The EET model is an enterprise annuity tax model that is tax-free at the purchase stage of the supplementary pension insurance business and the stage of fund utilization, and is taxed at the pension receiving stage. In the tax preferential policy, the monthly tax

\footnotetext{
${ }^{2}$ Data source: 2018 China Labor Statistical Yearbook

${ }^{3}$ Data source: Reported on the press conference of the State Council Information Office of the People's Republic of China on February 26, 2018.

${ }^{4}$ Data source: The 2018 National Enterprise Annuity Fund business data released by the Ministry of Human Resources and Social Security of the People's Republic of China in 2019.

${ }^{5}$ Data source: 2018 China Labor Statistical Yearbook.
} 
allowance for each person is RMB1000, the investment income is tax-free, and the personal income tax is paid according to the regulations when the retirement age is reached. This model commenced trial operations in 2018, and no significant results have been achieved yet.

However, unlike other countries, although China's social pension system is constantly improving, family pension is still the mainstream way of providing support to the elderly. In a typical social questionnaire survey in Beijing in 2011, only $9.3 \%$ of healthy retired elderly people chose community pensions or old-age care institutions. Overall, the main old-age pension for China's aging population is a family pension, accounting for $96 \%$ in $2016 .{ }^{6}$ The main reason behind this fact is that social pensions were not implemented early enough. It was not until 1991 that the Decision on Reform of Enterprise Employees' Pension Insurance System was issued, the Decision on Establishing a Unified Basic Pension Insurance System for Enterprise Employees was issued in 1997, and the pension system was only then established. The second reason is that aging is serious. By 2018, in China, the number of people over the age of 65 was 166 million, accounting for more than $11.9 \%$ of the population (United Nations 2018). The increase in average life expectancy, the decline in fertility rates, and the fertility boom before the implementation of family planning have made China's demographic structure extremely unbalanced. As more and more people enter the aging stage of life, China's social pension system has not been kept up, and only children can make up for the pension gap.

\section{Data source and descriptive statistics}

\section{Data source}

The data, in the present study, was obtained from the CSS of the CASS for the years 2017, 2015, 2013, and 2011. Since the survey data for 2006 and 2008 do not include expenditures for supporting relatives, data for these 2 years were not used. The survey was launched in 2005 by the Institute of Sociology of the CASS, and it is a large-scale, nationwide, and continuous sample survey project. Its purpose is to obtain data on China's social changes during transition periods. The content encompasses personal work status, family production and living conditions, quality of life, social security, social integration, national and social evaluation, social participation, and values and social evaluation. The CSS is a biennial longitudinal survey. Five surveys were completed in 2006, 2008, 2011, 2013, and 2015 using probability sampling. The survey area covers 31 provinces/autonomous regions/municipalities in China, including 151 districts, cities and counties, and 604 villages/residential committees. Each survey interviewed about 7000 to 10,000 families. The CSS survey data not only give the specific data of diverse household consumption but also lists a series of data such as the age and education level of parents and spouse's parents. In the 2017, 2015, 2013, and 2011 surveys, 9691, $10,243,10,205$, and 7036 valid questionnaires were collected, respectively, matching the family maintenance expenditure in the CSS data of each year with the number of the elderly population in the family. By default, children under the age of 22 cannot support their parents. Household heads over 60 years of age no longer need to bear the maintenance responsibilities; such responsibilities are transferred to their children and grandchildren. A total of 27,264 effective samples were selected from households with

${ }^{6}$ Data source: https://t.qianzhan.com/fengkou/detail/161003-db80b510.html\#comment, July 10, 2020. 
heads under the age of 60 and over 22, whose total household income and expenditure were greater than zero.

Variable

Explained variable

They are the proportion of daily consumption (con), the proportion of core consumption $(c c r)$, and the proportion of marginal consumption ( $m c r)$. Regarding household consumption, according to consumer preference theory, consumption preferences at different income levels are also different. Therefore, the crowding-out effect of elderly support expenditure on different consumption is also different.

\section{Explanatory variable}

Support expenditure on elders (including one's own parents, own grandparents, spouse's parents, and spouse's grandparents) with higher seniority is the amount that the respondent transfers to the elders each year (sfes). To reduce the impact of the extreme value of the skewed distribution, the ratio of elderly support expenditure to total household expenditure was taken as the maintenance burden rate.

\section{Control variable}

This study examines the crowding-out effect of elderly support expenditure on household consumption from the perspective of population aging. To verify aging besides quantitatively examining the crowding-out effect of maintenance expenditure on household consumption, it is obligatory to match the characteristics of children with the characteristics of elders. The total number of elderly people in the CSS database who are aged 60 years and above is recorded as (old).

After matching, as shown in Fig. 2, in all the samples the number of elders over 60 years of age who need support is 0 , and the average elderly support expenditure is RMB1680; the number of elders over 60 years of age who need support is 1 , and the average elderly support expenditure is RMB1703; the number of elders over 60 years of age who need support is 2, and the average elderly support expenditure is RMB2098; the number of elders over 60 years of age who need support is 3 , and the average elderly support expenditure is RMB2510; the number of elders over 60 years of age who need support is greater than or equal to 4 , and the average elderly support expenditure is RMB3559. Obviously, it was found that the higher the number of elders over 60 years of age in the household who need support, the higher the average amount of support expenditure. Likewise, families without elderly people over 60 years of age also need to provide parents a certain amount of support costs, because the Chinese pension system cannot provide adequate coverage, and parents who lose their ability to work prematurely have to rely on their children's support.

Elderly support is generally based on the family. Therefore, the average annual income per family (pcai) was obtained by dividing the total household income by the number of households. In the empirical process, we included the logarithm of the annual per capita household income, gender (male $=1$, female $=0$ ), household savings and household wealth, since they can also affect household consumption. Since the CSS survey data do not provide a specific survey result of household savings, according 


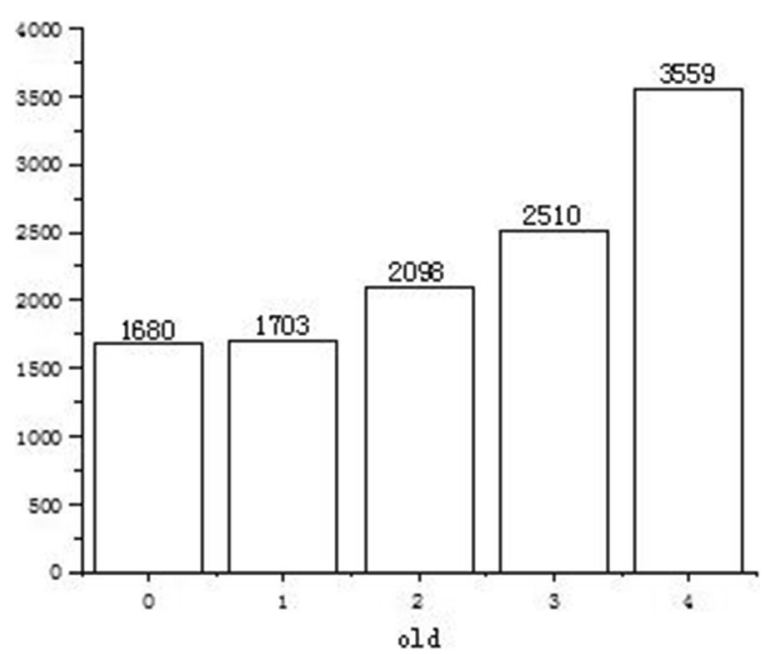

Fig. 2 The average elderly support expenditure in different households. Source: Calculated based on data from the CSS of the CASS in 2017, 2015, 2013 and 2011

to China's national conditions, we used the number of household-owned real estate (house) to represent household savings. Family scale (scale) was measured by the total population of the family, where family was defined as living together; their marital status (mar: married $=1$ or unmarried $=0$ (separated, divorced, widowed, and never married)) was also taken into consideration.

\section{Endogeneity}

Expenditure on household consumption is affected by many factors, such as personal characteristics, family background, economic ability, and work. There will be some omitted variables as well. Different consumption types have different consumption elasticity. Elderly support expenditure will inevitably offset other consumption. Due to the limitation of data and methods, the model has certain endogenous problems. We cannot control all the variables that affect daily, core, and marginal consumption, which leads to biased benchmark regression results. To a certain extent, it will affect the accuracy and robustness of the model.

To solve the endogenous problems caused by omitted variables and explanatory variables themselves, while examining the crowding-out effect, this study used the education level $(e d u)$ and age of respondents (age) as instrumental variables. Educational attainment $(e d u)$ was ascertained by confirming the number of years of education based on academic qualifications. According to China's specific national conditions, different academic qualifications need different years of education. Therefore, the assigned values are as follows: no school experience $=0$, primary school $=6$, junior middle school $=9$, high school $/$ secondary school $/$ vocational high school $=12$, college $=15$, undergraduate $=16$, and graduate student $=19$. First, the education level of the respondents is highly correlated with the education level of their parents. To a certain extent, it reflects the economic capacity and social status of the family, indicating that parents have more time, money, and abundant social resources. More likely than not, there is no need to rely on children for support. The age of the respondents is highly correlated 
with the age of the elders they need to support. Besides, age represents a certain level of working capacity and consumption expenditure on health care. Therefore, both instrumental variables satisfy the correlation hypothesis. On the other hand, each household's preference for different types of consumption is related to factors such as the income elasticity of that consumption, the characteristics of the household, and individual preferences. However, it is less relevant to the age and education level of respondents. Thus, the instrumental variables satisfy the exogenous hypothesis. These two variables can fundamentally eliminate the endogenous problems. Next, in the empirical part, this article will explain in detail the test of instrumental variables. Table 1 presents the descriptive statistical results of all variables.

\section{Factors affecting elderly support expenditure}

The factors that influence elderly support expenditure mainly include three aspects: family per capita annual income, respondent's characteristics, and family characteristics. In this empirical study, we sought to verify whether the crowding-out effect of elderly support expenditure would be different for different samples of old. Here, we simply used the ordinary least squares (OLS) regression method to examine what factors will affect elderly support expenditure, and the degree of impact. In particular, we explored whether the number of people over 60 years of age in need of support will have a negative effect on elderly support expenditure. Table 2 shows the results of the benchmark regression by the OLS method after controlling for gender, age, marriage, and other factors.

Table 1 Descriptive statistics of variables

\begin{tabular}{|c|c|c|c|c|}
\hline Variable & & Description & Mean & STD \\
\hline $\begin{array}{l}\text { Elderly support } \\
\text { expenditure }\end{array}$ & Insfes & The logarithm of expenditure on dependent elders & 3.1410 & 3.7937 \\
\hline Daily consumption ratio & con & Daily consumption expenses / total household expenditure & 0.6580 & 0.2364 \\
\hline Core consumption ratio & $\mathrm{cCr}$ & Core consumption expenses / total household expenditure & 0.2505 & 0.2238 \\
\hline $\begin{array}{l}\text { Marginal consumption } \\
\text { ratio }\end{array}$ & $m c r$ & $\begin{array}{l}\text { Marginal consumption expenses / total household } \\
\text { expenditure }\end{array}$ & 0.0647 & 0.1451 \\
\hline $\begin{array}{l}\text { The average annual } \\
\text { income per family }\end{array}$ & Inpcai & The logarithm of total household income / total population & 8.859 & 2.0899 \\
\hline $\begin{array}{l}\text { The burden of } \\
\text { supporting dependent } \\
\text { elders }\end{array}$ & pod & $\begin{array}{l}\text { Expenditure on dependent elders / Total family } \\
\text { expenditure }\end{array}$ & 0.0265 & 0.0567 \\
\hline $\begin{array}{l}\text { Number of elderly } \\
\text { people }\end{array}$ & old & Number of elders over 60 years old & 1.1238 & 1.2607 \\
\hline Family scale & scale & The total population of the family living together & 4.2918 & 1.7454 \\
\hline Gender & gen & Male $=1$, female $=0$ & 0.4375 & 0.4960 \\
\hline Real estate & house & The number of household-owned real estate & 1.135 & 0.6222 \\
\hline Marriage & mar & Married $=1$, unmarried $=0$ & 0.8969 & 0.4345 \\
\hline Years of education & edu & $\begin{array}{l}\text { No school experience }=0 \text {, primary school }=6 \text {, junior } \\
\text { middle school }=9, \text { high school/secondary school/ } \\
\text { vocational high school }=12 \text {, college }=15 \text {, undergraduate }= \\
16 \text {, and graduate student }=19\end{array}$ & 10.403 & 3.9505 \\
\hline Age & age & Age (years) & 43.510 & 10.306 \\
\hline
\end{tabular}

Source: Calculated according to the CSS data of 2017, 2015, 2013, and 2011 
Table 2 Basic regression results

\begin{tabular}{|c|c|c|c|c|c|c|}
\hline Variable & (1) & (2) & (3) & (4) & (5) & (6) \\
\hline old & $\begin{array}{l}0.6847^{* * *} \\
(38.71)\end{array}$ & $\begin{array}{l}0.6756^{* * * *} \\
(38.35)\end{array}$ & $\begin{array}{l}0.6737^{* * *} \\
(38.07)\end{array}$ & $\begin{array}{l}0.6887^{* * *} \\
(38.74)\end{array}$ & $0.678^{* * *}(38.03)$ & $\begin{array}{l}0.6779^{* * * *} \\
(38.02)\end{array}$ \\
\hline Inpcai & - & $0.165^{* * *}(15.53)$ & $\begin{array}{l}0.1642^{* * *} \\
(15.35)\end{array}$ & $\begin{array}{l}0.1468^{* * *} \\
(13.46)\end{array}$ & $\begin{array}{l}0.1457^{* * *} \\
(13.36)\end{array}$ & $0.146^{* * *}(13.38)$ \\
\hline house & - & - & $0.0636^{*}(1.77)$ & $0.0995^{* * *}(2.75)$ & $0.1009^{* * *}(2.79)$ & $0.1017^{* * *}(2.82)$ \\
\hline scale & - & - & - & $\begin{array}{l}-0.1035^{* * *} \\
(-7.86)\end{array}$ & $\begin{array}{l}-0.1147^{* * *} \\
(-8.64)\end{array}$ & $\begin{array}{l}-0.115^{* * *} \\
(-8.67)\end{array}$ \\
\hline mar & - & - & - & - & $0.3653^{* * *}(7.03)$ & $0.3624^{* * *}(6.96)$ \\
\hline gen & - & - & - & - & - & $\begin{array}{l}-0.042(- \\
0.94)\end{array}$ \\
\hline $\begin{array}{l}\text { Intercept } \\
\text { term }\end{array}$ & $\begin{array}{l}2.3716^{* * *} \\
(79.40)\end{array}$ & $0.9197^{* * *}(9.37)$ & $0.8628^{* * *}(8.26)$ & $\begin{array}{l}1.4032^{* * *} \\
(11.23)\end{array}$ & $1.1435^{* * *}(8.8)$ & $1.163^{* * *}(8.83)$ \\
\hline Sample size & 27,453 & 27,453 & 27,453 & 27,453 & 27,453 & 27,453 \\
\hline
\end{tabular}

Overall, the results of analysis with elderly support expenditure as the dependent variable showed that the regression coefficients of models (1) to (6) were statistically significant. Specifically, the estimated coefficients in model (1) reflect the direct effect of the number of elderly households on elderly support expenditure. As the number of (old) increases, so does the elderly support expenditure. In models (2) to (6), control variables were incrementally added: the higher the household per capita income of respondents, the higher the elderly support expenditure. On the other hand, the larger the household size, the lower the elderly support expenditure. This may be because the elderly and their adult children live together in a large family, thus reducing part of the cost of living, such as water, electricity, and gas expenses. In addition, living together allows elders to be better taken care of and reduces health care expenses to a certain extent.

In model (6), after controlling for variables such as income, gender, and marital status, the number of people aged above 60 years in need of support has a positive effect on elderly support expenditure, that is, for each additional elderly person who needs support, elderly support expenditure will increase by $74.4 \%\left(e^{0.6779}-1=0.744\right)$. Therefore, the more the elderly population in the respondents' households, the more the elderly support expenditure. If both parents and grandparents are present and they can still work during middle age, adult children do not need to bear the full burden of elderly support and are more likely to receive some financial assistance or life care from their parents or grandparents. Once parents and grandparents enter the aging category, incapacity to work is accompanied by high medical expenses. Even if only one of the parents and grandparents is still alive, the elderly who have lost the care and companionship of their partners are more prone to physical or mental ailments. At this time, adult children must take on the heavier responsibility of supporting their elders. Besides, from model (6), it can be perceived that a spouse has a greater impact on elderly support expenditure. Elderly support expenditure in married households is $43.7 \%$ $\left(e^{0.3624}-1=0.437\right)$ higher than that in unmarried families. When adult children are not married, parents are essentially at a stage where they can take care of themselves. They have good financial ability. They do not require support from their adult children; rather, they sometimes also give their adult children some financial assistance, such as 
in buying a house. The family planning policy for the past 30 years has allowed many families to have only one child. When the only child forms a family with another only child, they have to face the burden of supporting four elderly people. It makes sense that married families bear a heavier burden of supporting their elders.

\section{Model and empirical results}

Model

The basic model of the crowding-out effect of elderly support expenditure on household consumption is:

$$
y_{i t}=c+\beta P+\delta X_{i t}+\gamma_{t}+\theta_{t}+\mu_{i t},
$$

where $c$ is a constant term, and the explained variable $\left(y_{i t}\right)$ is household consumption expenditure. In addition to total household expenditure, this study divides household consumption expenditure into three parts, namely, the proportion of daily consumption (con), the proportion of core consumption (ccr), and the proportion of marginal consumption $(m c r)$. The following empirical experiments used different types of consumption as the explained variables for regression separately. The explanatory variable $\left(X_{i t}\right)$ is the proportion of expenditure (pod) of respondent's $(i)$ household on supporting elders in the year $(t)$. $P$ is the control variable: the variables of the average annual income per family (ln pcai), family scale (scale), the number of 60-year-old population in need of support (old), and marriage (mar); $\gamma$ and $\theta$ are dummy variables, corresponding to individual and time effect, respectively.

Since consumer expenditure is a continuous variable and varies considerably, to eliminate the influence of unobservable factors, we mainly used fixed effects for estimation. However, since the fixed-effect model ignores the endogenous nature of elderly support expenditure, and because there may be some bias in the estimated results, we had to eliminate the endogenous influence. Under the assumption of spherical disturbance, the two stage least square (2SLS) is the most effective. However, after testing for heteroscedasticity and autocorrelation, we found that the disturbance term has heteroscedasticity and autocorrelation. Therefore, this study chose a more effective generalized method of moments (GMM) estimation. We built the panel GMM model; the age (age) and education level $(e d u)$ of respondents were estimated as instrumental variables. To avoid the problem of selection bias as much as possible and control for variables such as respondents' gender, marriage status, and family scale, we explored the crowdingout effect of elderly support expenditure on the consumption of different types of households. The number of elders aged above 60 years who are dependent is the main variable that affects elderly support expenditure.

\section{Regression analysis}

Based on the above modeling ideas, Table 3 reports the benchmark regression results by applying fixed-effect estimation and panel GMM estimation. As previously indicated in this article, consumption was divided into daily consumption, core consumption, and marginal consumption. Models (1) and (2) in Table 3 represent the regression results of the effect of elderly support expenditure on daily consumption. Models (3) and (4) represent the regression results of the effect of elderly support expenditure on core consumption. Models (5) and (6) represent the regression results of the effect of elderly 
Table 3 Regression results of elderly support expenditure on different types of consumption

\begin{tabular}{|c|c|c|c|c|c|c|}
\hline \multirow[t]{3}{*}{ Variable } & \multicolumn{2}{|l|}{ con } & \multicolumn{2}{|l|}{$c c r$} & \multicolumn{2}{|l|}{$m c r$} \\
\hline & (1) & (2) & (3) & (4) & (5) & (6) \\
\hline & $\mathrm{FE}$ & GMM & $\mathrm{FE}$ & GMM & $\mathrm{FE}$ & GMM \\
\hline pod & $\begin{array}{l}-0.3826^{c} \\
(-5.64)\end{array}$ & $\begin{array}{l}-0.30464^{c} \\
(-9.88)\end{array}$ & $\begin{array}{l}-0.3637^{c} \\
(-5.59)\end{array}$ & $\begin{array}{l}-0.5008^{b} \\
(-2.03)\end{array}$ & $\begin{array}{l}-0.2537^{c} \\
(-5.26)\end{array}$ & $2.5472^{C}(10.96)$ \\
\hline pcai & $\begin{array}{l}-0.00003 \\
(-0.02)\end{array}$ & $0.0023^{c}(2.74)$ & $\begin{array}{l}-0.0061^{c} \\
(-3.15)\end{array}$ & $\begin{array}{l}-0.0051^{c} \\
(-7.67)\end{array}$ & $\begin{array}{l}0.0061^{c} \\
(4.76)\end{array}$ & $0.0028^{c}(4.52)$ \\
\hline scale & $\begin{array}{l}-0.0076^{c} \\
(-3.22)\end{array}$ & $\begin{array}{l}-0.0075^{c} \\
(-6.64)\end{array}$ & $0.0083^{c}(3.70)$ & $\begin{array}{l}0.0024^{c} \\
(2.68)\end{array}$ & $\begin{array}{l}-0.0007 \\
(-0.48)\end{array}$ & $0.0051(5.96)$ \\
\hline gen & $0.0022(0.27)$ & $0.0059^{b}(1.75)$ & $\begin{array}{l}-0.0092 \\
(-1.21)\end{array}$ & $\begin{array}{l}-0.0074^{c} \\
(-2.73)\end{array}$ & $0.007(1.41)$ & $0.0015(0.58)$ \\
\hline mar & $0.0024(0.31)$ & $0.0072^{\mathrm{a}}(1.82)$ & $0.0007(0.1)$ & $\begin{array}{l}-0.0025 \\
(-0.79)\end{array}$ & $\begin{array}{l}-0.0031 \\
(-0.69)\end{array}$ & $\begin{array}{l}-0.0047 \\
(-1.57)\end{array}$ \\
\hline house & $\begin{array}{l}-0.0092 \\
(-1.26)\end{array}$ & $\begin{array}{l}-0.0075^{c} \\
(-2.78)\end{array}$ & $\begin{array}{l}-0.0216^{c} \\
(-3.29)\end{array}$ & $\begin{array}{l}-0.0077^{c} \\
(-3.56)\end{array}$ & $\begin{array}{l}0.0308^{c} \\
(6.00)\end{array}$ & $0.0152^{c}(7.49)$ \\
\hline old & $\begin{array}{l}-0.182^{c} \\
(-5.27)\end{array}$ & $0.0052^{b}(2.39)$ & $0.0249^{c}(7.81)$ & $\begin{array}{l}0.0107^{c} \\
(6.16)\end{array}$ & $\begin{array}{l}-0.0067^{c} \\
(-3.00)\end{array}$ & $\begin{array}{l}-0.0158^{c} \\
(-9.72)\end{array}$ \\
\hline Intercept term & $\begin{array}{l}0.6944^{c} \\
(30.42)\end{array}$ & $\begin{array}{l}0.7447^{c} \\
(61.68)\end{array}$ & $\begin{array}{l}0.2785^{c} \\
(12.26)\end{array}$ & $\begin{array}{l}0.3011^{c} \\
(31.1)\end{array}$ & $\begin{array}{l}-0.0074 \\
(-0.5)\end{array}$ & $\begin{array}{l}-0.0457^{b} \\
(-5.02)\end{array}$ \\
\hline \multirow{2}{*}{$\begin{array}{l}\text { Instrument } \\
\text { variable }\end{array}$} & \multicolumn{6}{|l|}{ edu } \\
\hline & \multicolumn{6}{|l|}{ age } \\
\hline Weak IV test & - & 128.915 & - & 128.915 & - & 128.915 \\
\hline Sargan P-value & - & 0.5102 & - & 0.2570 & - & 0.7394 \\
\hline Sample size & 27,264 & 27,264 & 27,264 & 27,264 & 27,264 & 27,264 \\
\hline
\end{tabular}

support expenditure on marginal consumption. In general, the coefficients of elderly support expenditure were all negative and statistically significant.

The results of columns (1), (3), and (5) show that elderly support expenditure has a significant negative impact on consumption, with the largest crowding-out effect on daily consumption. Overall, the imperfect pension system has tilted the burden of old people's pension on young people, which has affected household consumption patterns to a certain extent. However, due to the potential endogeneity of the model, the age and education level of interviewees were introduced as instrumental variables in the empirical process. The panel GMM method was used for empirical study, and the estimated results are reported in columns (2), (4), and (6) of Table 3. Both Weak and Sargan tests show that the use of GMM model with instrumental variables is generally effective. There are no problems with weak instrument variables and overidentification. Therefore, there is no reason to reject the validity of instrumental variables. Based on the significance of each variable and the test index, the panel GMM estimation is significantly better than that of the fixed-effect model.

Overall, an increase in support for the elderly will crowd out other consumption of adult children's families. The more the support for the elderly, the greater the degree of crowding-out effect. It should also be noted that total family income is not fixed, and family members lose their financial capacity when they become old. At this time, the family loses one of its financial resources and has to support an elderly person; consequently, it has to reduce other expenditure to tide over the difficulties. After controlling the endogenous issues through GMM, the estimated results of daily consumption and core consumption did not change significantly and were still negative. Among them, 
the impact of the proportion of elderly support expenditure on core consumption expanded; that is to say, elderly support expenditure had a crowding-out effect on most of household consumption. However, in the GMM model, the crowding-out effect on marginal consumption changed from negative to positive. This is determined by the nature of the three major consumption. Daily consumption is only necessary for daily life, but core consumption is necessary and inevitable consumption related to the basic operation of the family, and it must have sufficient financial support. Elderly support expenditure is included in core consumption. Marginal consumption is selective consumption after satisfying the first two types of consumption. In reality, the order of importance of these three types of consumption is as follows: daily consumption, core consumption, and marginal consumption. Most households allocate their expenditure according to their relative importance. However, the burden of raising children by middle-aged people who were born after the introduction of family planning is heavy. Marginal consumption has been squeezed, so there is little room for change. The empirical results show that the crowding-out effect on core consumption is the largest, which is also very consistent with the current situation.

To examine the crowding-out effect of elderly support expenditure on consumption in the context of aging, we divided the sample into different sub-samples by the number of 60-year-olds to be supported. The panel GMM method was used to estimate the crowding-out effect of elderly support expenditure in different sub-samples on different consumption. The empirical results are shown in Tables 4, 5, and 6 .

Table 4 shows the estimated results of the impact of elderly support expenditure on the proportion of daily consumption in different samples. It can be seen from the results that in the samples of old $=0$ and old $=1$, the coefficients of the impact were 2.352 and -2.696 , respectively. Significant at the 5\% confidence level, the weak instrument variable test values were 151.7 and 19.1. This shows that there was no weak instrument variable problem; thus, it passed the over-identification test. The estimated results of the samples are credible. In the samples of old $=2$ and old $>2$, they failed the weak instrument variable and over-identification test. However, from the results, the impact coefficient did not fluctuate significantly. It shows that the influence of the proportion of elderly support expenditure on the proportion of daily consumption expenditure does not fluctuate greatly with the increase in the number of elders who need to be supported. It is obvious that the greater the number of elders who need to be supported, the greater the crowding-out effect of elderly support expenditure on daily consumption. The function of daily consumption is to meet the basic needs of a household. This is the same way of thinking as the Engel coefficient, which means that the higher the proportion of daily consumption, the lower the standard of living of the

Table 4 Impact of elderly support expenditure on daily consumption in different samples (GMM)

\begin{tabular}{lllll}
\hline Variable & $\mathbf{( 1 )}$ & $\mathbf{( 2 )}$ & $\mathbf{( 3 )}$ & $\mathbf{( 4 )}$ \\
& old $=\mathbf{0}$ & old = & old = & old $>\mathbf{2}$ \\
\hline con & $-2.352^{\mathrm{b}}(-8.39)$ & $-2.696^{\mathrm{b}}(-3.29)$ & $-2.686(-1.41)$ & $-2.796^{\mathrm{a}}(-2.26)$ \\
Control variable & yes & yes & yes & yes \\
Weak IV test & 151.7 & 19.1 & 2.99 & 5.55 \\
Sargan P-value & 0.1320 & 0.7824 & 0.0000 & 0.0046 \\
Sample size & 11,984 & 6013 & 5070 & 4197 \\
\hline
\end{tabular}


Table 5 Impact of elderly support expenditure on core consumption in different samples (GMM)

\begin{tabular}{lllll}
\hline Variable & $\mathbf{( 1 )}$ & $\mathbf{( 2 )}$ & $\mathbf{( 3 )}$ & $\mathbf{( 4 )}$ \\
& old $=\mathbf{0}$ & old $=\mathbf{1}$ & old $\mathbf{2}$ & old $\mathbf{2}$ \\
\hline ccr & $-0.7818^{\mathrm{a}}(-3.22)$ & $-0.4291(-0.62)$ & $1.538(0.86)$ & $0.2612(0.26)$ \\
Control variable & yes & yes & yes & yes \\
Weak IV test & 151.7 & 19.1 & 2.99 & 5.55 \\
Sargan P-value & 0.4996 & 0.8410 & 0.1123 & 0.0731 \\
Sample size & 11,984 & 6013 & 5070 & 4197 \\
\hline
\end{tabular}

household. It also shows that the income elasticity of daily consumption is relatively small. As a result, families will not prioritize reducing their daily consumption for elderly support expenditure.

Table 5 shows the estimated results of the impact of elderly support expenditure on the proportion of core consumption in different samples. Controlling for other factors remains unchanged. It can be seen from the results that in the samples of old $=0$, the coefficient of the impact was -0.7818 . Significant at the $5 \%$ confidence level, the weak instrument variable test value was 151.7. This shows that there was no weak instrument variable problem, and it passed the over-identification test. The estimated results of the sample are credible. However, regarding the samples of old $=1$, old $=2$, and old $>2$, the results were not significant, and the coefficient of influence was positive when old $=$ 2 , and old $>2$. On further OLS estimation of the three samples of old $=1$, old $=2$, and old $>2$, the results show that they are significant at the 5\% level, with impact coefficients of $-0.495,-0.516$, and 0.458 , respectively. We speculate that this result may be because core consumption includes health care consumption. Although elderly support expenditure will squeeze out core consumption, the more the elders aged over 60 years who need to be supported, the more health care expenditure, leading to an opposite crowding-out effect of elderly support in different old samples.

Table 6 shows the estimated results of the impact of elderly support expenditure on the proportion of marginal consumption in different samples. It can be seen from the results that in the samples of old $=0$ and old $=1$, the coefficients of the impact were 2.1335 and 2.125, respectively. Significant at the 5\% confidence level, the weak instrument variable test values were 151.7 and 19.1. This shows that there was no weak instrument variable problem, and it passed the over-identification test. The estimated results of these two samples are credible. The samples of old $=2$ and old $>2$ did not pass the weak instrumental and over-identification test, and the coefficient fluctuates considerably. On further OLS estimation of the two samples old $=2$ and old $>2$, the

Table 6 Impact of expenditure on supporting elders on marginal consumption in different samples (GMM)

\begin{tabular}{lllll}
\hline Variable & $\mathbf{( 1 )}$ & $\mathbf{( 2 )}$ & $\mathbf{( 3 )}$ & $\mathbf{( 4 )}$ \\
& old $=\mathbf{0}$ & old $=\mathbf{1}$ & old $=\mathbf{2}$ & old $>\mathbf{2}$ \\
\hline$m c r$ & $2.1335^{\mathrm{b}}(10.17)$ & $2.125^{\mathrm{b}}(3.74)$ & $0.1477(0.15)$ & $1.535^{\mathrm{a}}(1.91)$ \\
Control variable & yes & yes & yes & yes \\
Weak IV test & 151.7 & 19.1 & 2.99 & 5.55 \\
Sargan P-value & 0.2182 & 0.5200 & 0.0000 & 0.0308 \\
Sample size & 11,984 & 6013 & 5070 & 4197 \\
\hline
\end{tabular}


results show that both are significant at the $5 \%$ level, with impact coefficients of -0.128 and -0.142 , respectively.

In 2019, the per capita disposable income of Chinese residents was RMB30,733, a nominal increase of $8.9 \%$ over the previous year. After deducting price factors, the real increase was 5.8\%. Per capita disposable income is less than RMB3000 per month. ${ }^{7}$ Chinese families generally attach importance to education and will spend more than their own ability on education. Therefore, a certain proportion of households can only maintain subsistence and medical care for members when a large amount of money is invested on education, and cannot afford marginal consumption. By observing all the original samples, it can be found that many households have no marginal consumption. In other words, the income of these households can only maintain daily and core consumption, and marginal consumption has been crowded to the point where there is almost no expenditure. This may be the cause of insignificant results. Since the proportion of households with marginal consumption is small and the sample is small, there are differences between empirical conclusions and theories. In addition, it is possible that highincome households generally spend more on marginal consumption. These families may increase expenditures on recreational activities in order to better take care of their parents when elderly support expenditure increases.

\section{Conclusion}

The crowding-out effect of the aging population on household consumption is obvious. This study is based on 4 years of data of the CSS from the CASS, a total of 27,264 micro household survey sample data. First, it analyzed the factors that affect elderly support expenditure. Second, the relationship between elderly support expenditure and the consumption of different types of households was examined from a micro level. We reached the following main conclusions. First, the greater the number of elderly people over the age of 60 who need to be supported, the higher the annual per capita household income; the greater the number of real estates and the smaller the family size, the higher the family support expenditure. Married families have higher maintenance expenditure than single families. Second, household elderly support expenditure has a crowding-out effect on different types of household consumption. The higher the elderly support expenditure, the more other types of consumption are crowded out. However, not being completely crowded out, family savings will fill part of the vacancy. Third, the crowding-out effect is different for different consumption. The crowding-out effect on core consumption is the largest, followed by daily consumption. However, the effect on marginal consumption is insignificant, because the marginal consumption of most Chinese households has been squeezed to the lowest limit, and there is no room for reduction. Fourth, the crowding-out effects of elderly support expenditure on daily consumption, core consumption, and marginal consumption were separately analyzed in samples of different household elderly populations. In general, the larger the elderly population, the heavier the burden on households in terms of daily consumption, and the greater the crowding-out effect of elderly support expenditure. In the case of core

${ }^{7}$ Data source: The National Bureau of Statistics released the 2019 National Economic and Social Development Statistical Bulletin. 
consumption, since health care expenditure is also included in core household expenditure, it results in a situation where the more the elderly people in the household, the more core consumption expenditure is incurred. For marginal consumption, the crowding-out effect of elderly support expenditure is not significant across samples with different numbers of elderly people.

This research has important policy implications. First, it aids in improving the Chinese pension system, so that the elderly population is not solely, or mainly, dependent on their children's pension, which is a matter that will benefit generations of people. Emancipating young and middle-aged people from the burden of supporting their parents can release their consumption power, improve their quality of life, and promote economic development. Second, the side-effects of the onechild policy are gradually emerging. The 4-2-1 family model is very stressful for adult children. Therefore, if the Chinese government liberalizes the second-child policy, it should gradually loosen the birth restriction. This would not only slow down the aging of the population, but would also alleviate the pressure on family pensions. Finally, the Confucian "filial piety" culture is deeply rooted in China. The elderly with higher socioeconomic status can afford their consumption. The elderly who do not have pensions or whose pensions are insufficient to maintain daily life have to their children for support and reduce their consumption levels. Therefore, providing appropriate positions to the elderly who have retired (but can still work) and encouraging them to work after retirement can alleviate the pressure on their children to a certain extent.

A household with low-income is unable to provide better resources and education for their children. When the parents grow old, these children will have to bear the burden of support far beyond their ability. This invisible inequality transmitted intergenerationally further expands China's Gini coefficient, exacerbates the urban-rural dichotomy, and at the same time aggravates the insufficient consumption of the whole society. Future research should focus on whether there is family heterogeneity in the crowding-out effect of population aging on household consumption. It should also focus on whether the impact on urban and rural households is different, and what the difference is. Another research direction can also be the impact of family medical consumption expenditure on supporting parents when children and parents do not share income or expenditure. It is also worth discussing the different positions of men and women in supporting parents and the impact of having children of their own on the expenditure of supporting parents.

To sum up, these discussions are only preliminary insights into the crowding-out effect of supporting parents' expenditure on household consumption, and some simple conclusions have been drawn. Due to the complexity of the potential motivation behind intergenerational transfer behavior, the heterogeneity of families, and the influence of policies, etc., further research is needed in the future.

Abbreviations

CPI: Consumer Price Index; CSS: Comprehensive Social Survey; GDP: Gross Domestic Product; OLS: Ordinary Least Squares 
encouragement and guidance. We also appreciate Professor James Johnston, who is from University of the West of Scotland in the UK, for his constant encouragement and language polishing.

\section{Authors' contributions}

$\mathrm{CH}$ mainly takes charge of researching in the theoretical part of the paper. GX plays a guiding role in the revising the paper. LC takes charge of a writing role of the empirical part. All authors read and approved the final manuscript.

\section{Funding}

This article is supported by Science and Technology Project of Jiangxi Provincial Department of Education (No. GJJ191661).

\section{Availability of data and materials}

The data supporting the findings of the article are available in the China Academy of Social Sciences Comprehensive Social Survey Data in 2017,2015,2013,2011 at http://css.cssn.cn/css_sy/zlysj/Insj/.

\section{Ethics approval and consent to participate}

All procedures performed in studies involving human participants were in accordance with the ethical standards of the institutional and/or national research committee and with the 1964 Helsinki declaration and its later amendments or comparable ethical standards.

\section{Consent for publication}

Not applicable.

\section{Competing interests}

The authors declare that they have no competing interests.

Received: 1 April 2020 Accepted: 13 January 2021

\section{Published online: 30 March 2021}

\section{References}

Abraham, M. (1954). Motivation and personality. Nueva York: Harper \& Row Publishers.

Becker, G. S. (1974). A theory of social interactions. Journal of Political Economy, 82(6), 1063-1093.

Becker, G. S. (2009). Human capital: A theoretical and empirical analysis, with special reference to education. Chicago: University of Chicago Press.

Diamond, P. A. (1965). National debt in a neoclassical growth model. The American Economic Review, 55(5), 1126-1150.

Dyson, T. (2013). Population and development: The demographic transition. London: Zed Books.

Egri, C. P., \& Ralston, D. A. (2004). Generation cohorts and personal values: A comparison of China and the United States. Organization Science, 15(2), 210-220.

Feng, T., \& Ma, D. (2019). The subject choice of singleton parents for the elderly: A study on the influence of children's characteristics and intergenerational support. Journal of Xi'an Jiaotong University (Social Science Edition), 39(6), 76-83.

Goldin, C. (2016). How Japan and the US can reduce the stress of aging aging? (no. W22445). Working paper. New York: National Bureau of Economic Research.

Greenhalgh, S. (1985). Sexual stratification: The other side of "growth with equity" in East Asia. Population and Development Review, $11(2), 265-314$

Hareven, T. K. (1978). The dynamics of kin in an industrial community. American Journal of Sociology, 84, S151-S182.

Höpflinger, F., \& Hugentobler, V. (2003). Pflegebedürftigkeit in der Schweiz: Prognosen und Szenarien für das 21. Jahrhundert. Bern: Huber.

Kotlikoff, L. J. (1988). Intergenerational transfers and savings. Journal of Economic Perspectives, 2(2), 41-58.

Lai, D. W. L. (2012). Effect of financial costs on caregiving burden of family caregivers of older adults. Sage Open, 2(4), 2158244012470467.

Liang, H. (2014). Mental health status of migrant workers from the perspective of intergenerational differences. Population Research, 38(4), 87-100.

Lin, M., Liang, Y., \& Liu, L. (2014). A regional comparative study of the elderly pension status in China_Analysis based on the data of the sixth national census. Journal of Wuhan University of Science and Technology (Social Science Edition), 16(2), 204-208.

Long, F., \& Wang, J. (2015). The core consumption determinism - From the structural distortion of the market and consumption to see the fundamental influencing factors of insufficient domestic demand in China. Journal of Hebei University of Economics and Business, 36(6), 27-37.

Maslow, A. (1954). Motivation and personality. New York: Harper.

McGarry, K., \& Schoeni, R. F. (1995). Transfer behavior in the health and retirement study: Measurement and the redistribution of resources within the family. Journal of Human Resources, 30, S184-S226.

Ofstedal, M. B., Knodel, J., \& Chayovan, N. (1999). Intergenerational support and gender: A comparison of four Asian countries. Asian Journal of Social Science, 27(2), 21-41.

Ogawa, N., \& Retherford, R. D. (1997). Shifting costs of caring for the elderly back to families in Japan: Will it work? Population and Development Review, 23(1), 59-94.

Schwarz, B., Trommsdorff, G., Zheng, G., \& Shi, S. (2010). Reciprocity in intergenerational support: A comparison of Chinese and German adult daughters. Journal of Family Issues, 31(2), 234-256.

Shi, M., Jiang, Z., \& Qiu, X. (2019). How ageing affects the expenditure of household consumption in China-Evidence from Chinese social survey. Economic Theory and Economic Management, 4, 62-79.

State Council (1985). China 1982 census data. Beijing: China Statistics Press. 
United Nations (2017). World population prospects: The 2017 revision. United Nations Department of Economic and Social Affairs, Population Division Retrieved from: https://Esa.Un.Org.

United Nations. (2018). Human Development Index (HDI). Retrieved from: http://hdr.undp.Org/en/content/humandevelopment-Index-HDI.

Wang, G. (2019). 70 years of new China: Population age structure change and aging development Trend. China Population Science, (3), 2-15.

Wang, W., \& Liu, Y. (2017). Population aging and the upgrading of household consumption structure-An empirical study based on CFPS 2012 data. Journal of Shandong University (Philosophy and Social Sciences), (5), 84-92.

Wang, Y., Dan, D., \& Long, Y. (2019). Green book of China social security system • China social security system development report no.10. Beijing: Social Sciences Academic Press.

Wang, Y., \& Zhou, H. (2019). Research on the effect of population aging on urban household consumption level. Shanghai Economic Research, 5, 84-91.

World Bank. (2018). GDP Per Capita (Current US\$). Retrieved from: https://data.worldbank.org/indicator/NY.GDP.PCAP. CD?view=chart. Accessed 10 Sept 2020.

Xie, Y., \& Zhu, H. (2009). Do sons or daughters give more money to parents in urban China? Journal of Marriage and Family, $71(1), 174-186$.

Xu, Q. (2015). The son or the daughter pension? Based on comparative analysis within the family. Society, 35(4), 199-219.

Yin, Z. (2009). The choice of old-age parents' pension methods and the construction of the old-age model in the first batch of urban children in China. Population and Development, 3, 76-91.

You, S., \& Cai, Y. (2017). Dynamic analysis of the impact of population aging on economic growth—An empirical analysis based on panel VAR model. Economy and Management, 31(1), 22-29.

Zhang, C., \& Chen, B. (2014). Can "social pension" replace "family pension"?_Evidence from China's new rural social pension insurance. Economic Research, 49(11), 102-115.

Zhu, Q. (2016). Comment on the effect of population aging on income distribution. Social Scientist, 1, 54-60.

\section{Publisher's Note}

Springer Nature remains neutral with regard to jurisdictional claims in published maps and institutional affiliations.

Submit your manuscript to a SpringerOpen ${ }^{\odot}$ journal and benefit from:

- Convenient online submission

- Rigorous peer review

- Open access: articles freely available online

High visibility within the field

- Retaining the copyright to your article

Submit your next manuscript at $>$ springeropen.com 